\title{
Experiments with a Newly Developed Biogas Reactor Block
}

\author{
Mónika Bakos-Diószegi ${ }^{1}$, Miklós Horváth ${ }^{1}$ \\ ${ }^{1}$ Óbuda University, Donát Bánki Faculty of Mechanical and Safety Engineering, \\ Népszínház utca 8, H-1081 Budapest, Hungary, E-mail: \\ dioszegi.monika@bgk.uni-obuda.hu; horvath.miklos@bgk.uni-obuda.hu
}

\begin{abstract}
Increasing energy security can be found in the principal objectives of all countries. There is a competition in the research of long-term available renewable energy sources and their high efficiency utilization, and also in time. From the renewable energy sources the biomass, as an inexhaustible commodity was used in the experiments. Digestion was chosen from the several methods to explore green energy from waste and then to produce valuable biogas. However, the experiments related to anaerobic fermentation of organic materials take a long time, up to several months, so the results gained from these carefully prepared and accurately conducted experiments are definitely valuable. By optimizing the fermentation equipment it was possible to increase the time-efficiency of the measurements. The results are given in this paper.
\end{abstract}

Keywords: renewable energy; biogas; biogas reactor block

\section{Introduction}

Due to its natural features and agricultural and livestock past for centuries, Hungary is rich in biomass. This organic material is worth taking into consideration when selecting a method to produce biogas, which has not been used significantly in the country, so far. Experiments related to anaerobic fermentation of organic materials take a long time, so the results gained from these carefully prepared and accurately conducted experiments are definitely valuable. The fermentation block, the technological equipment used to conduct experiments, was optimized in order to increase the time-efficiency of the measurements. Some prototypes of the construction under development were tested several times, and finally a proprietary biogas unit was developed and installed, which is introduced below. 


\section{Pursuit of Energy Security}

The word "security" comes from the Latin phrase "sercus", which also has worryfree, careless meanings. According to Barry Buzan, the famous English political scientist, security is the possibility and ability to survive and subsist against the threats of existence. Buzan divided the phrase security into five sectors: military, political, economic, social and environmental. The Military Science Encyclopedia adds the humanitarian, environmental and disaster recovery sectors to them. [1]

One of the basic pillars of economic security is energy, without which the Member States of the European Union, among them Hungary, would not exist. Everyday life of individuals and states would be impossible without energy. Consequently, the pursuit aiming ensure of energy supply, is also involved in energy security. The excessive energy demand of the world influences everyday life of developed societies. The largest consumers are affected the most by the lurch of energy security. More than half of energy consumption of the European Union is imported. 53.8\% of energy consumption of the 27 member states has come from external sources. Net exporter during this period has only been Denmark. [2]

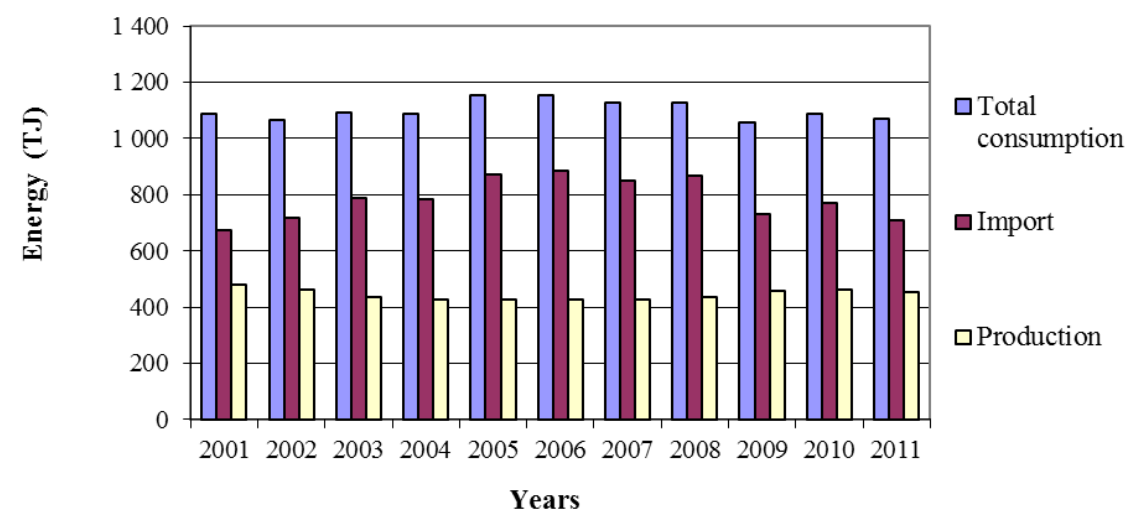

Figure 1

Energy balance of Hungary

The lack of coverage of domestic energy consumption derives especially from the increased consumption of oil and natural gas. Due to the gas program, that started at the beginning of the early 1990s, both the institutions and the population switched to gas consumption, significantly. As a result the gas dependence has increased by an additional $20 \%$ from 1995 .

The increased demand for raw materials has brought a large amount of gas imports, which made our country even more dependent to unpredictable foreign relations in the region. On the basis of the energy balance in 2011, it can be concluded that $66 \%$ of the country's energy consumption is imported. [3] 
The growth of renewable energies in electricity production has been observed since 2003. Although it increased from $1 \%$ to $8.1 \%$ by 2010 , Hungary is still among the last ones from the EU member states.

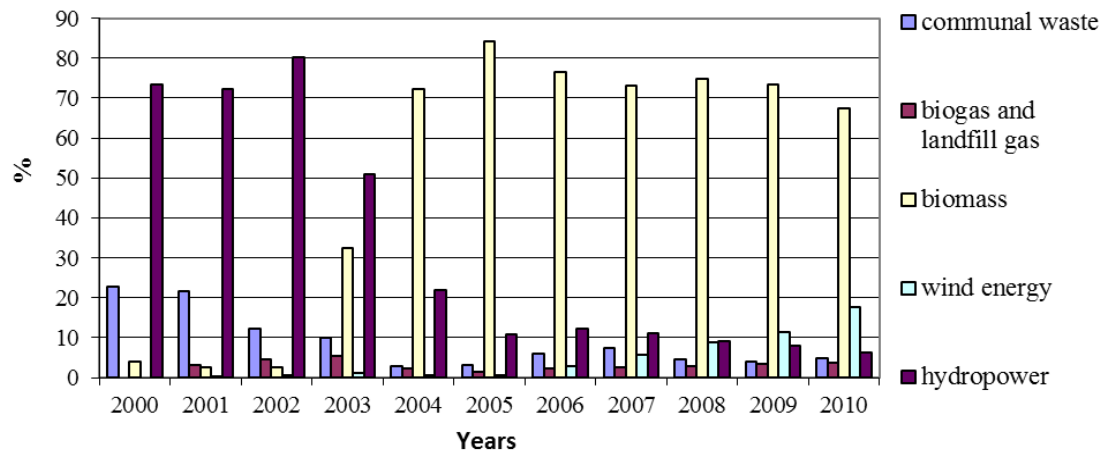

Figure 2

The proportion of renewable energy sources in electricity production

From the renewable energy sources the biogas has been used only from 2001 with a small amount of 6 TJ. This number was multiplied by 2010 to 1516 TJ, but still not close to the value inherent in the domestic biogas potential.

For comparison, in Sweden about 50\% of the heat energy is produced from biogas today. [4]

Environmental considerations also encourage constructions of biogas power plants all over the world.

Methane, which is 21 times more damaging greenhouse gas than carbon dioxide, contributes with a ca. $20 \%$ to the anthropogenic greenhouse effect. More than $50 \%$ of methane originates from animal husbandry. Its average degradation time in the atmosphere ( 8 years) is much shorter than that of carbon dioxide (50-200 years). [5] A solution to the efforts to reduce or prevent its free access to the atmosphere can be the controlled fermentation of crop and livestock by-products. The methane, generated in power plants, will not enter the atmosphere, and what is more, it is the perfect raw-material for energy production.

\section{Conditions of Organic Material Fermentation}

Despite the fact that the application and utilization of anaerobic degradation of organic materials is not new, the research of biogas is its infancy both in Hungary and in the world. The chemical-biological process is simple, since the fermentation of organic material can take place anywhere, where the conditions of anaerobic rotting are given. 
The degradation of complex organic materials takes place in several steps. First, the compound - sugar-chain polymer is broken up using exoenzymes of bacteria involved in the hydrolysis. The volatile organic acids obtained as the product of degradation are transformed further to acetate and hydrogen by acetogenic microorganisms. Approximately $70 \%$ of the final obtained methane is converted from acetate. The final step takes place strictly in anaerobic conditions, during which the methanogen microorganisms use up the ready-made volatile acids and produce methane and carbon-dioxide. The acetogens and methanogens exist in close symbiosis. The acetogenic bacteria prepare the nutrients for methanogens, which consume also the hydrogen. However, the presence of hydrogen affects unfavourably the operation of acetogens, so during their degradation methanogens stimulate the functioning of tribes located in front of them in the food chain. Consequently, the back and forth dependence between the different groups of microorganisms can be considered as syntrophic relationship, i.e. they not only help each other but they are interdependent in their diet.

In the process of biogas formation it is very important to provide parameters that stimulate degradation.

Biological conditions:

1. organic material

2. presence of acidogenic and methanogenic bacteria, including appropriate living conditions for them. [6]

The necessary living conditions:

1. anaerobic environment,

2. appropriate solid content of raw material (2-9\% in the case of wet process),

3. constant, balanced fermentation temperature, (anaerobic biodegradation takes place either on mesophilic $\left(30-35^{\circ} \mathrm{C}\right)$ or thermophilic temperatures $\left(50-55^{\circ} \mathrm{C}\right)$ in a biogas unit that includes the fermenters),

4. continuous agitation to avoid a gas barrier film, local acidification and temperature difference, as well as to prevent foaming,

5. sufficiently chopped and mixed raw material( for better gas yield),

6. slightly alkaline $\mathrm{pH}$, sufficient $\mathrm{C} / \mathrm{N}$ ratio of the base material.

The aim of the research was to produce biogas in laboratory conditions.

During the experiments the effect of another factor, the stirring was also investigated. Altough it is not a condition of anaerobic degradation, digesters using organic materials should be stirred. The main effects of stirring in the case of biogas fermenters are that it prevents solids from settling in the fluid, homogenize the medium and makes biological processes more intensive. Thus, the surface available for bacteria responsible for gas production will increase and the volume of biogas produced will also increase. However, the energy demand of stirring is high, so its application is uneconomic. Laboratory experiments carried out in Germany proved that there was not significant difference in biogas yields 
during anaerobic batch fermentation of corn silage when the stirring was intermittent and continuous. However, with intermittent stirring - $10 \mathrm{~min}$ stirring 230 minutes break - 29\% energy saving was achieved in relation to the continuously stirred technology. [7]

In Denmark, a similar study was conducted with cow manure degradation. In this case, the volume of the generated methane was $12.5 \%$ higher when intermittent stirring was applied, compared with continuous stirring. [8]

On the basis of the above listed results and our own experiments the intermittent stirring was chosen, which is optimal in terms of biogas yield and energy use, too.

Conditions, discussed above had to be ensured for proper degradation. The system has operated more and more optimal, little by little, and was modified according to the results of the previous test case.

\section{Implementation of the Experiment}

Conditions needed to the optimal degradation process, mentioned above, are provided by a fermenter. In biogas plants this task is carried out by a huge concrete tank, in which the biogas is generated in temperature controlled, hermetically sealed and stirred conditions, usually with continuous input/output of the base material.

\section{Model 1}

In our laboratory it was an anaerobically sealed, heat-resistant glass vessel of 1 litre that served as a fermenter (1), in which we could measure the temperature and the $\mathrm{pH}$ continuously (3). There was a gas collecting bag (8), silicone tubes (4), a 3-way valve (6) and also a sampling cap (7) necessary to sampling gas. At the beginning we could not solve stirring (2), and we could not afford buying a gas meter (5).

The gas sampling component functioned properly, which was confirmed by the gas chromatographic analysis. It was a good choice to use the commercially available bags for collecting the gas, because it can be recycled, avoiding environment pollution. The hermetically sealed vessel, the $\mathrm{pH}$-meter, the silicone and connected fittings also operated properly.

The primary issue raised by putting the basic concept into practice was the measuring the quantity of the gas generated. We could not afford buying a gas mater suitable for detecting low flow, laboratory quantity gas, because of their high prices. It was also a problem that the fermentation liquid has not been heated yet, and so it could not provide the optimal mesophilic $\left(37{ }^{0} \mathrm{C}\right)$ degradation 
temperature. Furthermore, it appeared urgent to solve the stirring, to provide a homogeneous degradation process.

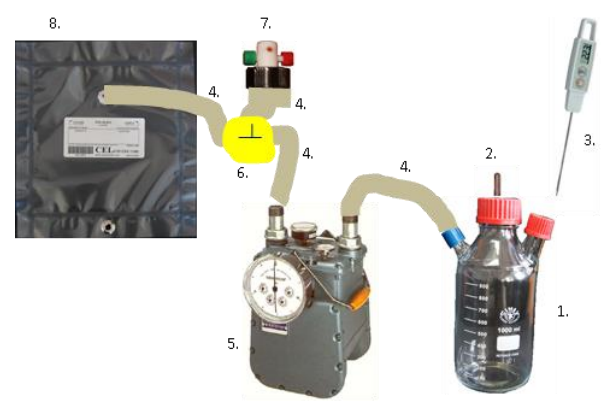

Figure 3

Model 1 [9] [10] [11]

\section{Model 2}

Model 2 was designed to eliminate the shortcomings and problems arose during operating Model 1 . To provide insulation and heating combined with stirring the construct shown below was developed (Figure 4).

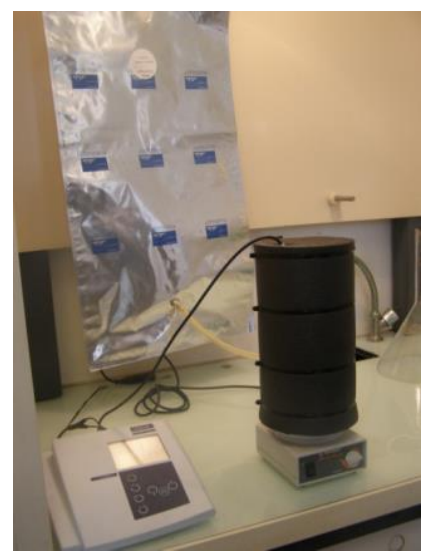

Figure 4

Model 2

The installed heating magnetic stirrer appeared to be a good choice for heating; however it was not suitable to provide the sufficient homogeneity of the substrate. The generally resulting $7-8 \%$ dry matter content was too high, so it was necessary to find a new solution for stirring the raw material. The polyfoam insulation was acceptable for experiment, but we have not been able to find a good solution to measure the quantity of the generated gas in that phase of the research. 


\section{Model 3}

The main difference compared to the first two variants is a construction suitable for measuring the volume of the generated gas and for keeping the constant temperature of $37^{\circ} \mathrm{C}$. The homogeneous and constant temperature was achieved by placing the fermenter into a dryer which was used as an incubator cabinet (Figure 5). The dryer ensured the constant $37{ }^{\circ} \mathrm{C}+/-1{ }^{\circ} \mathrm{C}$, required to the measurements, perfectly.

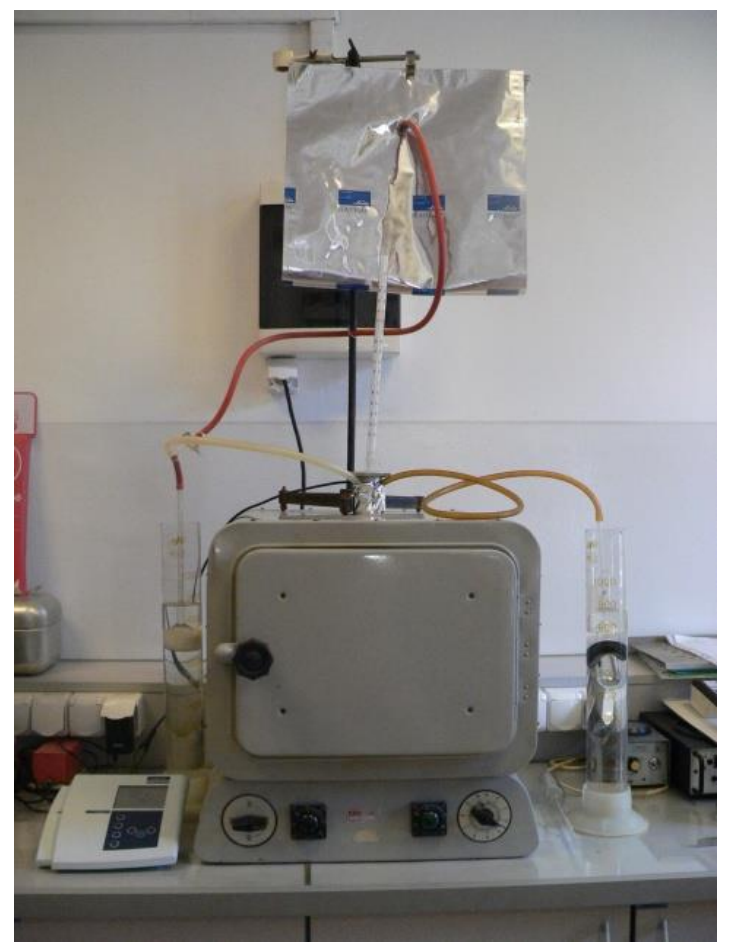

Figure 5

Model 3

To determine the volume of gas produced, the volume displacement method was used, which is very easy to implement and its accuracy is in accordance with standard recommendations.

The volume of the generated gas equals to the volume of liquid displaced, and its pressure without compression is $101325 \mathrm{~Pa}$. The apparatus consisted of a graduated cylinder of $1000 \mathrm{ml}$, and placed inside the „, squealer”, an open ended glass cylinder with a smaller cross-sectioned, tight nozzle. The gas flowed from the fermenter into the „squealer" from the silicone tube, which was led out of the dryer. As a result, the volume of the supersaturated $\mathrm{NaCl}$ solution, which was 
originally at the same level in the graduated cylinder, has changed. The biogas flow generated by fermentation pumped a volume equal to its own volume from the "squealer" to the graduated cylinder. The volume of the gas produced was measured with an accuracy of $10 \mathrm{ml}$.

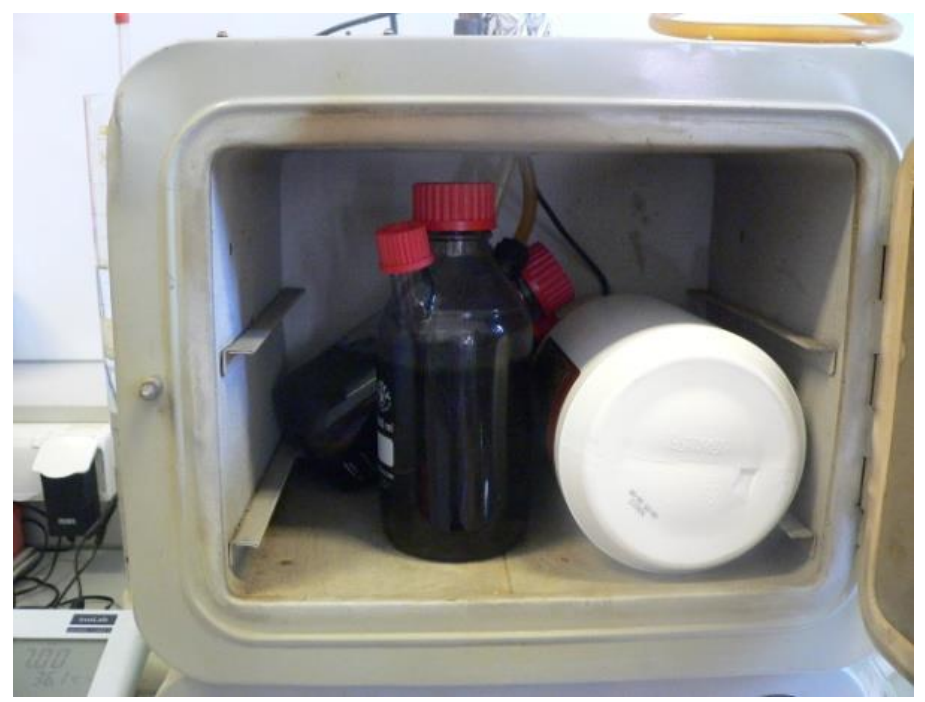

Figure 6

The dryer with the fermenter inside

Model 3 could perfectly provide the constant experimental temperature and also the measurement of the volume of gas generated.

However, during testing Model 3 it was found that to ensure homogeneity of the sewage sludge and preventing foaming, stirring must be provided. Earlier it was replaced by shaking the vessels in the same intervals.

\section{Implementation of a New Construction}

Significant changes were made in the construction of the new model. Our main objective was to make a device that complies with measuring procedures in the fermentation standard (VDI 4630). According to the standard the degradation process has to take place in several glass vessels simultaneously. We planned to build 8 fermenter blocks, but the dryer appeared to be too small for them, and so a plastic crate filled with water was used for controlling the temperature of the fermenter. The number of the openings of fermenter glasses was also changed. 4 openings with threaded silicone caps were needed for the stirring, input, output and gas outlet. 


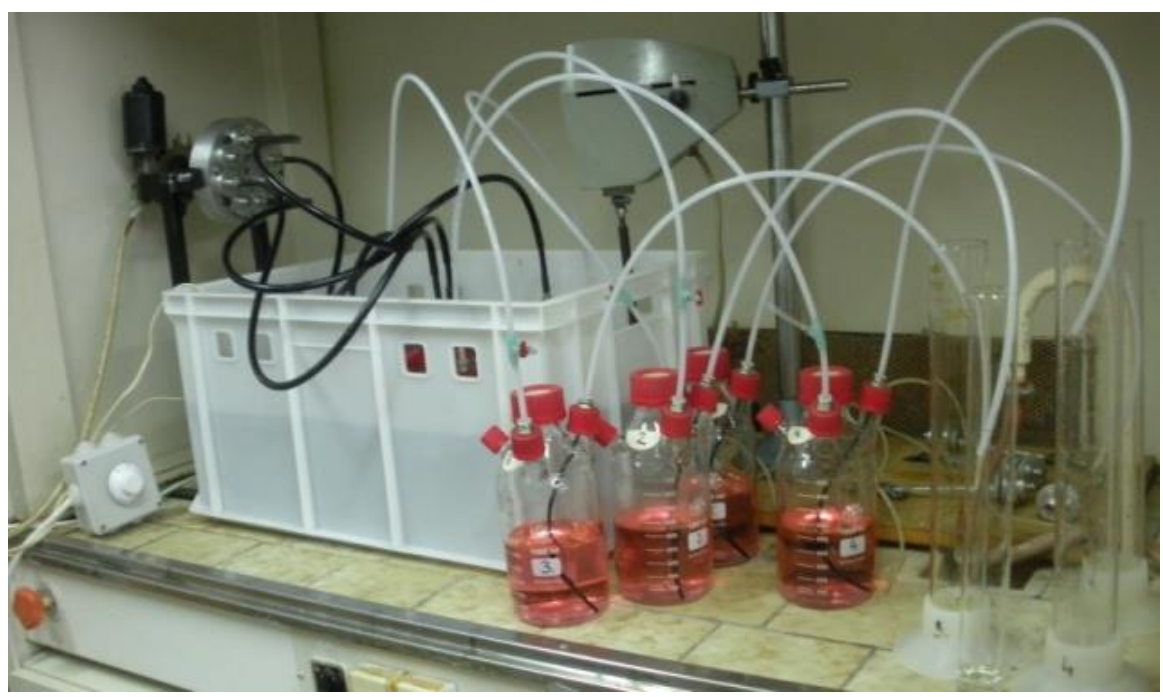

Figure 7

The complete construction

It was also a significant change compared to the previous constructions that the stirring was solved in the 8 fermentation glasses. The 8 stirrers were built into the largest, center pipe, worked simultaneously, driven by a wiper motor. The required number of rotation was provided by a drive unit consisting of 8 gears.
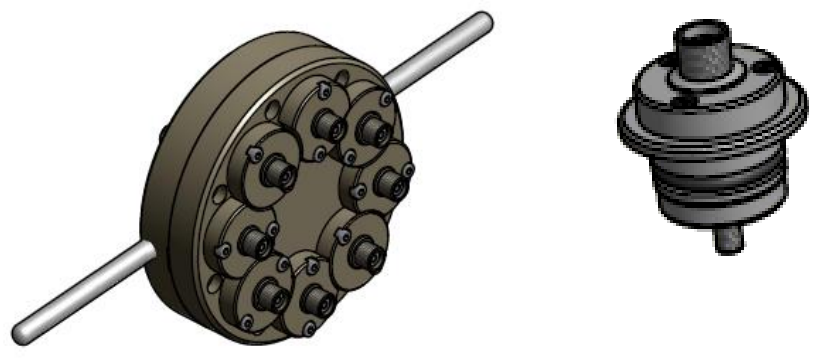

Figure 8

The gear box and the gas-tight connector plug

The shaft coming out of the reduction gearbox was connected to the stirrers by Bowden cables with form-locking connection and with gas-tight connector plugs, built in the caps. The other connectors of the glass vessels were fitted with quick coupling, which ensured adequate gas barrier. 


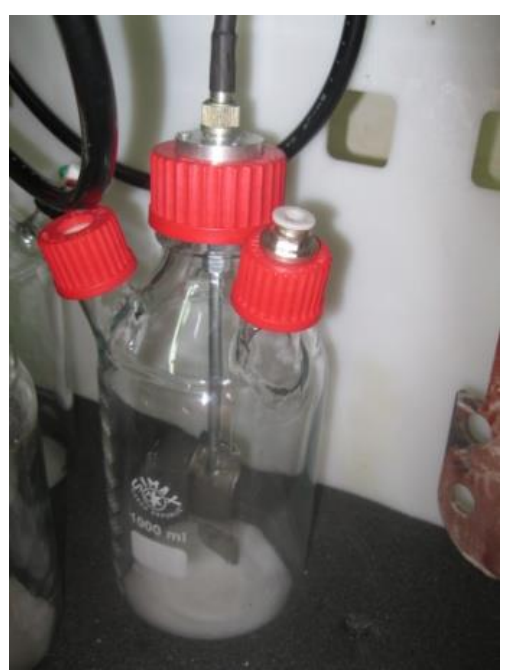

Figure 9

The glass fermenter

Although we kept the principle of positive displacement flow, the „squealer" construction was no longer used for the gas flow measurements. From each fermenter (1) placed in a water bath a silicone tube (2) led the generated gas (3) out. This tube was led to the top of another glass bottle which contained supersaturated $\mathrm{NaCl}$ solution (4). There was another tube (5) from the bottom of that bottle, through which the gas pumped the solution to the graduated cylinder (6). This way, it was possible to measure the volume of the generated gas accurately, on a daily basis, according to the standard specifications.

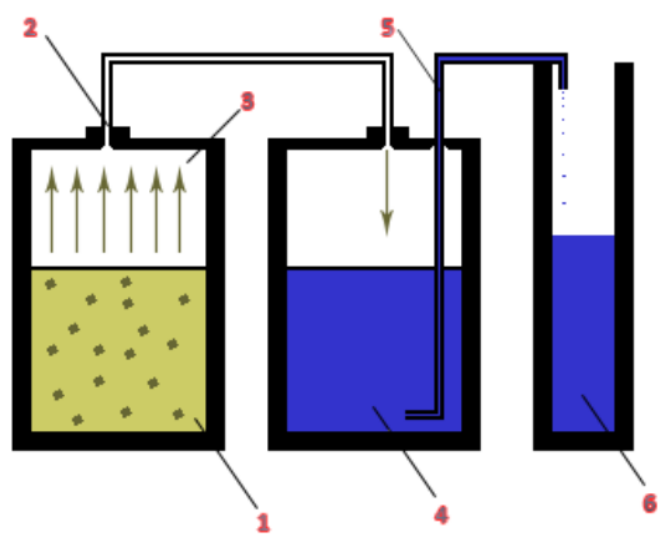

Figure 10

Gas volume meter 
To keep the temperature of the water bath constant in the plastic crate a heating element, a thermostat and circulating vanes were used. When the temperature of the wate fell below the settled value of $37{ }^{\circ} \mathrm{C}$, the sensor switched on the heating and circulating at the same time.

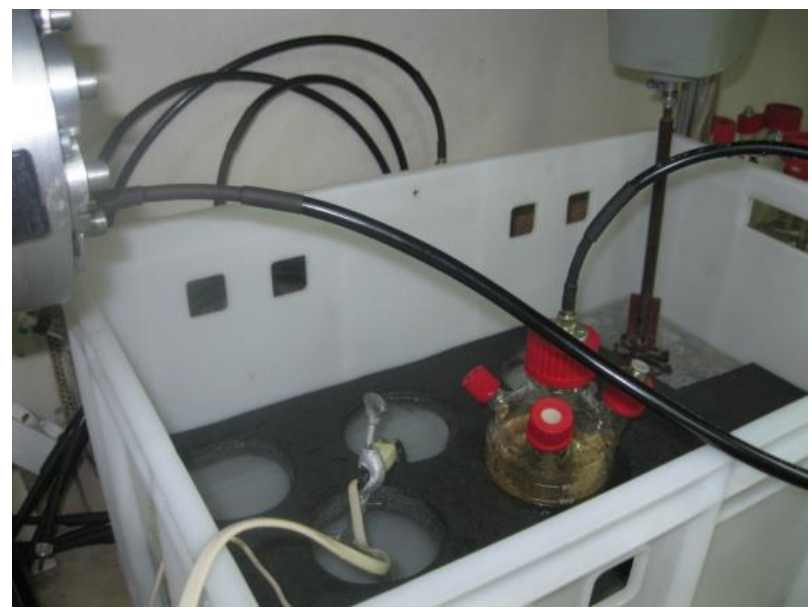

Figure 11

Insulation and water circulating

To increase the inertia of the temperature and to prevent the fermenters floating up in the water, a polyfoam board (with holes cut for the bottles) was fitted on the bottom of the crate.

\section{Test Experiment with the Newly Developed Biogas Fermenter Block}

The experiment was performed by using four fermenters of net one liter each, which were placed into water bath. Sludge taken from waste water channels in Budapest was used as seeding sludge, and chopped then wheat straw, fractionated by sieves, was used as substrate.

The inoculum of $2,55 \%$ dry matter and $64.63 \%$ organic dry matter content ensured the microorganism medium which was to help the degradation.

The wheat straw had $95.78 \%$ dry matter and $93.41 \%$ organic dry matter content. Each fermenter was examined at net volume of $700 \mathrm{ml}$.

Fermenters 1 and 2: with wheat straw of $0,125-2 \mathrm{~mm}$ particle size and sludge, without mixing. 
Fermenters 3 and 4 : with wheat straw of $0,125-2 \mathrm{~mm}$ particle size and sludge, with 2 min stirring 60 minutes break.

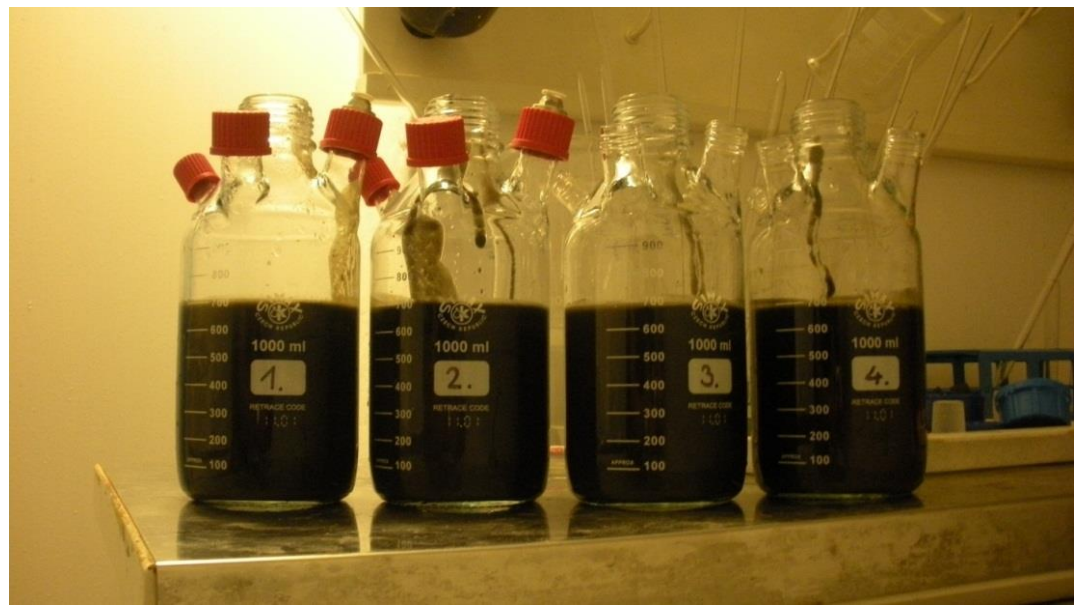

Figure 12

The four fermenters filled with sludge

The middle threaded orifices of bottles 1 and 2 were closed by silicone sealing sheets. In bottles 3 and 4 there were stirrers that were hanged in as far as $1 / 3$ of the bottle height from the bottom and they were to make the digested substrate homogeneous.

The fermenters with wheat straw-seeding sludge substrates were placed into a temperature controlled bath of $37^{0} \mathrm{C}$.

The produced gas from the four fermenters was led into four additional collector bottles where because of the increased pressure of the gas the liquid was displaced. The displaced liquid was collected in measuring cups, so the volume of the produced gas could be read with an accuracy of $1 \mathrm{ml}$.

During the experiment the continouosly generated gas was collected in a special gas storage bag by using a three-way pipe. In the course of the repeated 24-day experiment samples were taken from the daily „fresh” gas.

It can be concluded that due to the stirring, that made the substrate more homogenous, the efficiency of digestion increased.

The gas yield increased from $180 \mathrm{ml} / \mathrm{goTS}$ to $223 \mathrm{ml} / \mathrm{goTS}$. This value corresponds to the value recorded in the literature for average biogas yield of wheat straw. [12] 


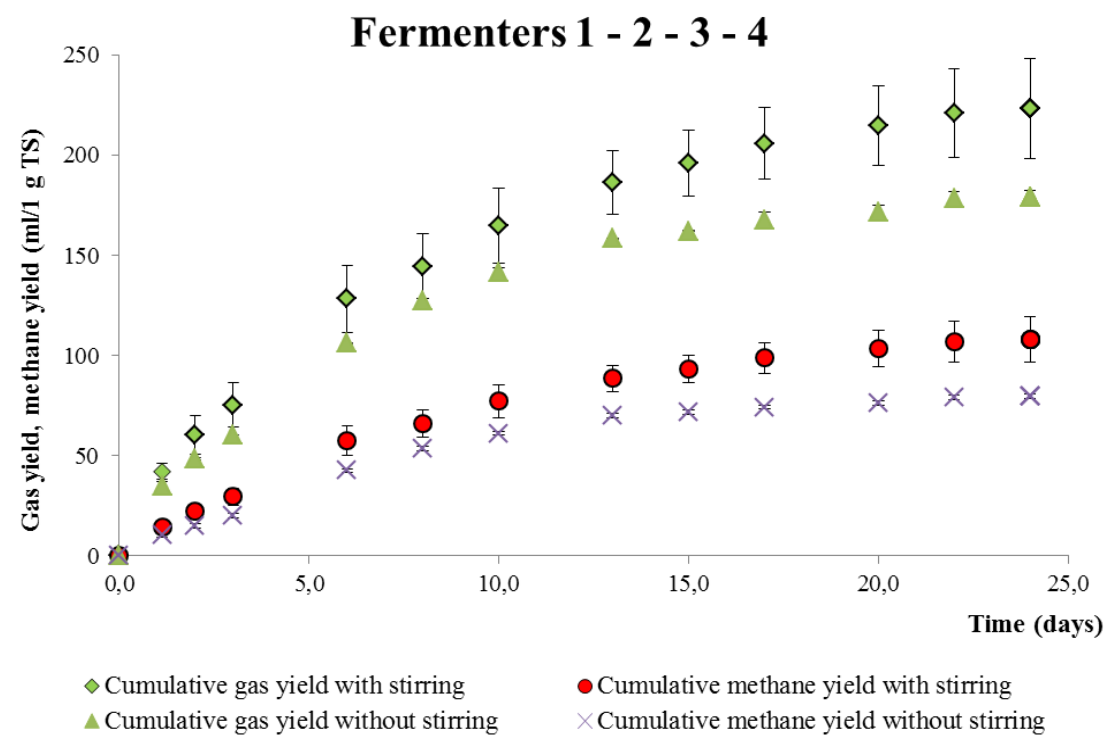

Figure 13

Gas yield and methane yield with (1 and 2) and without (3 and 4) stirring

Fermenters 1 and 2 showed a minimum variance in respect of both the biogas and methane yields. At the end of the 24-day parallel measurements a $3.2 \mathrm{ml} /$ goTS biogas and a $2.5 \mathrm{ml} / \mathrm{goTS}$ methane yield deviation was experienced.

A more significant deviation was recorded in respect of the biogas and methane yields in the case of fermenters 3 and 4 . The total variance of the cumulative gas yield value reached $22.1 \mathrm{ml} / \mathrm{goTS}$, which was $9.9 \%$ of the generated total value of $223 \mathrm{ml} /$ goTS biogas. In the case of methane content the cumulative variance was $11.4 \mathrm{ml} /$ goTS, which was $10.6 \%$ of the generated total value of $107.9 \mathrm{ml} / \mathrm{goTS}$.

\section{Summary}

The results of the experiment proved that the operation of fermenters 1 and 2 without stirring was stable and gas-tight. Fermenters 3 and 4 , which were equipped with stirring vanes, and which produced approximately $10 \%$ variation in both, biogas and methane yields, require further constructional modification.

At the end of the developing process the final, automatic and discontinuous biogas reactor block was achieved. The developing process was performed according to Guideline VDI 4630 (Fermentation of organic materials, Characterisation of the substrate, sampling, collection of material data, fermentation tests) [13].The realization was performed in several stages, which were considered as milestones. In order to make our research work even more effective and representative our further objective is to make the operation of the biogas fermenter block more reliable, regarding gas-tightness stability. 


\section{Acknowledgements}

Thank you for helping certain subtasks of the developments: Klaudia Kormos, Ferenc Haraszti, Zoltan Laky and Otto Etler.

\section{References}

[1] Magyar Hadtudományi Társaság: Hadtudományi Lexikon I. kötet. Szabó József (főszerk.). - Budapest, 1995. - ISBN 9630452278

[2] Statisztikai tükör IV. évfolyam 58. szám http://www.ksh.hu/docs/hun/xftp/stattukor/energiaarak0409.pdf

[3] Magyarország megújuló energia hasznosítási cselekvési terve 2010-2020 A 2020-ig terjedő megújuló energiahordozó felhasználás alakulásáról, Nemzeti Fejlesztés, 2010 december Budapest http://geotermia.lapunk.hu/tarhely/geotermia/dokumentumok/national_rene wable_energy_action_plan_hungary_hu.pdf

[4] Biogas Road Map for Europe, http://www.aebiom.org/IMG/pdf/Brochure_BiogasRoadmap_WEB.pdf

[5] Biogas from waste renewable resources, Dieter Deublein, Angelika Steinhauser; http://zorgbiogas.com/upload/pdf/Biogas_from_Waste_and_Renewable_Re sources.pdf

[6] Bai A.: A biogáz, 2007 Száz magyar falu könyvesháza, ISBN 978-9637024-30-6

[7] Alexandra Kowalczyk, Eva Harnisch, Sebastian Schwede, Mandy Gerber, Roland Span - Different mixing modes for biogas plants using energy crops Applied Energy (2013) Volume 112, December 2013, pp. 465-472

[8] Prasad Kaparaju, Inmaculada Buendia, Lars Ellegaard, Irini Angelidakia Effects of mixing on methane production during thermophilic anaerobic digestion of manure: Lab-scale and pilot-scale studies, Bioresource Technology - Volume 99, Issue 11, July 2008, pp. 4919-4928

[9] http://www.conrad.hu/pic.php?pid=123320\&image=1

[10] http://www.celscientific.com/files/Tedlar_Bag.jpg

[11] Laboratóriumi gázáramlás mérő berendezés http://www.elster-americanmeter.com/en/707.html

[12] Kaltwasser, B. J. - Biogáz előállítás és hasznosítás. Budapest, Műszaki Könyvkiadó, 1983

[13] VDI 4630 (2006): Fermentation of organic materials - Characterisation of the substrate, sampling, collection of material data, fermentation test 